\title{
The Baltic States' Relations with Russia
}

\section{Carrington Matthews}

The Baltic states of Estonia, Latvia, and Lithuania have had cold relations with Russia since they were under the control of the tsarist Russian Empire. This paper examines the history behind the relationship between the Baltic states and the Soviet Union throughout the twentieth century and how the relationship grew colder in the post-Soviet era by examining a combination of scholarly journal articles and informative internet resources that detail recent events pertaining to the Baltic states and Russia. This investigation may shed light on the future of Baltic-Russian relations and help explain Russian intimidation in the Baltics. Today, the negative relationship between the Baltics and Russia is the result of discriminatory policies toward ethnic Russians residing in the Baltics and a series of territorial disputes and hostilities. The goal of the discriminatory policies is to promote a sense of "Baltic unity," or nationalism among ethnic Estonians, Latvians, and Lithuanians, while discouraging the practice of Russian language and culture. However, these policies have polarized ethnic Baltic and ethnic Russian populations, leading to Russian aggression. The territorial disputes primarily pertain to Estonia, which lost a piece of land to Russia in the Soviet era, and the invasion of Crimea, which significantly impacted Estonian concerns about their own national security. Russia's desire for geopolitical security along with other issues related to ethnic politics and territorial disputes are some of the reasons that the Baltic states and Russia have such strained relations today, and why Russian intimidation can be expected to increase in the future.

Keywords: raspad, ethnic politics, territorial disputes, Russia, Baltic states

\section{Introduction}

One of the most monumental events in twentieth-century Russian politics was the dissolution of the Soviet Union in December of 1991. One of its direct results was that the satellite nations which formerly made up part of the Soviet Union were given independence 
after being denied autonomous statehood for decades. Estonia, Latvia, and Lithuania, known collectively as the Baltic States, were given their independence by the Soviet Union in the months before its dissolution, an event commonly referred to as the raspad. The Baltic states each joined the North Atlantic Treaty Organization (NATO) and the European Union (EU) after the raspad, which symbolized the nations' allegiance to Western Europe while distancing them from Russian politics and culture. Today, Russia and the Baltic states have cold relations because of the Baltic states' efforts to become integrated, westernized European countries. The westernization of the Baltic states is a geopolitical loss for Russia, whose leaders want to maintain the buffer zone between Western Europe and Russia which they maintained for most of the twentieth century. In recent years, Russia has taken steps to keep the Baltic states within its sphere of influence in order to create a more intimate relationship between the countries. Russia's geopolitical concerns, the disenfranchisement of ethnic Russians in the Baltics, and Russian aggression pertaining to territorial disputes, are among the causes of icy relations between the countries over the past several years and indicate a pattern of Russian intimidation. In order to have a deeper understanding of recent Baltic-Russian relations, an exploration of the historical context must precede a closer analysis of ethnic politics, territorial disputes, and Baltic integration with the West.

\section{| Historical Context}

When examining recent foreign relations between Russia and the Baltic states, it is important to consider why the Baltic states are so strategically valuable to Russia, and therefore why Russia is committing aggressive acts towards the Baltic states in order to maintain its geopolitical security. History can provide this explanation. The Baltic states were geopolitically important to the Soviet Union. After World War II, Soviet leader Joseph Stalin wanted to create a "sphere of influence," or a geographic area surrounding Russia that was under Russia's control ("Soviet power"). Achievement of this foreign policy goal was immensely important for Russia because the country had been invaded several times over the past several centuries, most recently by Nazi leader Adolph Hitler in 1941 (Marshall 13). A sphere of influence would serve as a buffer zone between Russia and the capitalist Western European powers who were seen as a threat to the Soviet Union. The Baltic states, due to their geographic locations, provided a barrier between Russia and Western Europe, and they helped protect Russia from western invasions.

The Baltics were brought into the Soviet Union unwillingly, stripped of their independence in 1940 and forced to adopt a communist economy. Moreover, a policy of "Russification" was enacted, which meant that Russians were brought to break up the ethnic unity of the region, and Russian was adopted as the official language ("The History"). This led to even more animosity toward the Soviet Union, for the Baltics had only recently gained their independence in 1918 from Tsarist Russia, and before that were under control of Germany and Sweden ("History of Latvia"). The Baltic states had intentions to become westernized capitalist countries once they had their full independence from the Soviet Union. Considering that the national cultures of the Baltic states are more closely related to those of Western Europe than Eastern Europe and Russia, as well as the fact that the Baltic states suffered years of oppression under foreign governments, it is easy to understand why the Baltic states 
wanted to pursue integration with Western Europe ("The History"). In the months leading up to the raspad in 1991, the Baltic states finally gained national sovereignty. They declared their independence at the end of 1990, which the Soviet government recognized on September 6, 1991 ("Restoration"). However, rebuilding from decades of Soviet control and integrating into Western Europe would prove to be challenging for the Baltic states.

\section{Western Integration}

With independence finally in their grasp, the Baltic states pursued closer relationships with powerful Western countries. They did this by joining NATO and the EU. Perhaps most symbolic in the Baltics' cutting of ties with Russia and indicative of their future icy relationship with Russia was their refusal to join the Commonwealth of Independent States (CIS), an intergovernmental organization comprising all other former Soviet states ("Commonwealth"). This was all particularly alarming to Russia. Russia was losing its coveted sphere of influence that it wanted to maintain after the dissolution of the Soviet Union. Westernized countries suddenly shared borders with Russia, posing a military, political, and economic threat to the country. The steps the Baltic states took towards closer relations with Western Europe ultimately strained their relations with Russia. These strained relations have led to a prominence of ethnic politics within the Baltics and territorial disputes with Russia; both of these have increased tensions between the nations.

While the Baltics have long wanted to integrate themselves into Western Europe, doing so has led to problems in sustaining their economy. Latvia's economy, for example, suffered very much during the Great Recession. In 2009, facing a growing unemployment rate and a crumbling economy, the Latvian government asked for 7.5 billion dollars to bail out the country (Lannin and Johansson). The suffering economy, combined with already strained ethnic relations, led to riots in the capital of Riga, where protestors threw bottles at parliament and looted stores (Lannin and Johansson). Additionally, the population of the Baltic states has continued to decrease for decades. This is because the Soviets exiled many in the twentieth century, and emigration from the Baltics to the United States, Canada, and the rest of Europe has increased. Many Baltic peoples moved to the United States and Canada after the raspad because once the Iron Curtain fell, travel restrictions to these countries were lifted as well. They also moved to other parts of Europe because as members of the EU, they had the ability to travel to any member country without a passport. For the Baltic states, a declining population meant less people available to contribute to the Baltic economies. There were no longer as many people to create businesses and buy goods. This also meant that the Baltic states were losing a significant amount of talent-in other words, people who had crucial specialized skills and potential were emigrating.

The economic troubles of the Baltic states are important to consider when examining Baltic-Russian relations, for such economic downturn gives Russia an opportunity to use the situation to its advantage. Because the economies of each Baltic state are so small and Russia's economy is much larger, Russia could try to pressure the Baltic states into economic dealings to aid the Baltic economies while helping its own country geopolitically. One way that Russia could do this is through its network of oil and natural gas pipelines. The Baltic states have historically relied on Russian gas since the Soviet era and continue to rely on it (Hoellerbauer). 
Since Russia is the countries' primary provider of natural gas, Russia could raise the price of natural gas on the already fragile economies. Doing so could spell economic disaster for the Baltic states, who would lack the appropriate funds to pay for Russian gas. This puts Russia in a powerful position. Russia could keep the price of gas high and strain the Baltic economies, and then propose a form of economic or political agreement with the Baltics so that they do not lose access to the gas. Although the Baltics have taken steps towards integration with Western Europe, their economic positions leave the door open for Russia to maintain a certain degree of power over the Baltics. Economic troubles associated with western integration are only the beginning of the problems the Baltic states have been facing. Culturally, the Baltic states are still struggling to come to terms with their new, diverse national identities which came as a result of membership in the Soviet Union. This is best understood through examining the ethnic politics of the Baltic states today.

\section{| Ethnic Politics}

Ethnic politics have become more prominent in the Baltic states in the past several decades. Following the raspad, there was a Russian diaspora. Ethnic Russians were working and living in other member countries of the Soviet Union, and vice versa. Russian leaders called for ethnic Russians to return to Russia to help reconstruct the failed Soviet economy; however, some Russians did not return and instead stayed in the former Soviet country that they were already in. Therefore, the Baltic states today have a high population of ethnic Russians living within their borders. Estonia and Latvia have the highest percentages of ethnic Russians, who account for roughly 25 percent of their populations; Lithuania, however, has a much lower population of ethnic Russians at only 5.8 percent, which is less than the number of ethnic Poles living in the country (The World Factbook).

Estonia and Latvia in particular have long histories of disenfranchising their Russian populations; this is one of the primary reasons for Russian aggression in the past couple of decades. Following the raspad, these two Baltic countries declared that only those who were Estonian or Latvian before joining the Soviet Union, including their direct descendants, were citizens (Aasland 57). This means that primarily ethnic Estonians and Latvians were counted as citizens while Russians were excluded. This citizenship policy was put in place in an effort to create a stronger sense of nationalism through the idea of Baltic unity, and because Estonia and Latvia were concerned that the Russian population within their borders would destroy the Baltic identity and culture (Thompson 113). Today, this policy still stands, and it is challenging for ethnic Russians to earn citizenship. The Baltic states are widely multilingual, with each country practicing its own native language and still maintaining a large population that speaks Russian; in fact, in Estonia and Latvia, the percentage of people who speak Russian is roughly 30 percent (The World Factbook). In order to gain citizenship in Estonia, Russophones would have to take an Estonian language exam that tested their knowledge of the Estonian language in order to become naturalized citizens ("Obtaining Estonian"). They would have to learn a whole new language in order to apply for citizenship and therefore earn their right to vote. Estonia and Latvia claim that the Russians of today are descendants of those Soviet Russians who settled during the time the Baltics were forcibly "occupied" by the Soviet Union. Therefore, those Russians are not truly citizens, for their ancestors are 
occupiers (Thompson 111). Naturally, Russia reacted to this with hostility. Russians believe that the Baltics were never truly occupied, and that the language exam is unfair because it disenfranchises primarily ethnic Russians (Thompson 111, 112). Moreover, Russians already living in the Baltics feel that they are being discriminated against since they had been working hard to contribute to the economy of the Baltics under the rule of the Soviet Union (Aasland 60). The citizenship policy created so soon after the end of Soviet rule in the Baltics has served as the foundation for many other problems between the Baltics and Russia over the past several years. Predictably, disenfranchisement of ethnic Russians in the Baltics and Baltic citizenship policies have angered Russians. Taking away these rights demonstrates yet again that the Baltics are creating closer ties with Western Europe at the expense of their relations with Russia. Not only that, disenfranchisement of ethnic Russians means less Russian influence in the Baltic states.

The Baltic states have experienced internal strife between ethnic minorities because the population that identifies as ethnically Estonian, Latvian, and Lithuanian sees itself as Western, while the Russian population in each state sees itself as Eastern. Estonia has made the distinction between its Estonian and Russian populations by controlling territory that is ethnically Estonian and promoting the use of the Estonian language over the use of Russian (Aalto 69). Beyond encouraging the use of Estonian over Russian, Baltic governments have also pushed the idea of "Baltic unity" so as to build a stronger sense of nationalism among their peoples and further distance themselves from the Russian population within their borders (Veema 86).

A prime example of Estonian ethnic politics can be found in the region known as Narva. This region is in northeastern Estonia and has a population which is overwhelmingly made up of Russophones. In fact, only about 10 percent of the population of Narva is of the Setu group, which is culturally Estonian (Aalto 68). However, the Estonian government continues to try to spread its nationalist message to this region despite the low number of ethnic Estonians actually living there. Nationalist policies have had the opposite effect; rather than making the ethnic Russians feel welcome in Estonia, Russians feel like the government does not support them because of their ethnic roots (Veema 76, 77).

Ethnic politics in the Baltic states are perhaps best illustrated by the controversy surrounding the Bronze Soldier, a statue that was originally located just outside of the Estonian capital of Tallinn. It was erected by Soviets following the conclusion of World War II in order to commemorate soldiers who died in battle. However, this statue took the place of an Estonian statue that commemorated Estonia's independence, achieved in 1918 (Ehala 139, 140). The statue therefore is symbolic of the tension between ethnic Estonians and Russophones in the country. It became most symbolic of Soviet occupation in 2006, after two extreme Estonian protestors protested the Russophone celebration occurring at the statue; the Estonian media broadcasted this, which appealed to the emotions of ethnic Estonians and fueled hostilities towards Russophones (Ehala 145). Finally, in 2007, the Estonian Parliament voted to have the statue moved away from the center of the city to a cemetery, causing protests from Russophones. Riots occurred in Estonia, and in Russia a group of Russians tried to attack Estonian ambassador Marina Kaljurand, who was going to hold a press conference in the Estonian embassy in Moscow. As a result of this aggression, the Estonian embassy closed (McLaughlin). The Russian government reacted to this budding crisis as well by launching a cyber attack on Estonia in 2007 because of the Bronze Soldier incident; the cyber attacks 
shut down government websites and compromised government servers (Herzog 78, 79). This incident demonstrates the extent to which Russia is determined to maintain its sphere of influence over the Baltics. Although Estonia and the Bronze Soldier have been outside of Russian control for decades, Russia endeavors to maintain a certain degree of influence there, as noted above, so as to protect itself geopolitically from Western Europe. From Russia's perspective, removing Russian monuments is another act that symbolizes the Baltics taking steps away from Russian culture and influence; however, the Russian reaction to the Bronze Soldier incident have made cold relations even icier.

Ethnic politics and bitter histories have led Latvia and Russia to seek justice through the court system. In Latvia, the case Kononov v. Latvia was significant because Soviet partisan Vasiliy Kononov was tried for war crimes that were allegedly committed during World War II (Mälksoo 102). The ethnic politics practiced in the Baltic states have led to responses from Russians, who have brought court cases against Latvia in the European Court of Human Rights. The Russian government claims that Latvia is oppressing and discriminating against ethnic Russians in Latvia, and this allegation seems to have some substance. For example, in the case Petropavlovskis v. Latvia, an ethnic Russian living in Latvia wanted to become a naturalized Latvian citizen, but was denied citizenship status because of his involvement in protests of the Latvian "Education Law," which required schools to be taught in the Latvian language; therefore, he believed he was being punished for protesting the law (Heri). This case is another example of how the Latvian government is exercising its power to maintain a sense of Baltic unity and discriminate against ethnic Russians. It is obvious that Baltic unity, however, comes at a price. While ethnic Baltic populations may in fact feel more united, the divide between these populations and ethnic Russians has grown, and is highlighted in the many territorial disputes between the Baltics and Russia.

\section{| Territorial Disputes}

While each Baltic state has had political conflict with Russia over border issues, Estonia has had the most disputes, which stem from the 1920 Tartu Peace Agreement, signed when Estonia had its own independence and sovereignty (Stoicescu). While Estonia was part of the Soviet Union, the Soviet government changed the administrative line of the Pechory area in eastern Estonia and made the area part of the Pskov Oblast of Russia (Stoicescu). Once Estonia gained its independence again in 1990, the country wanted to maintain the border established by the Tartu Peace Treaty, giving Estonia back land that it legally possessed. However, the Russian government claimed that the treaty became void once Estonia joined the Soviet Union, so they were unwilling to return the land to Estonia (Kundu 62). Since then, there have been various attempts on the part of the Estonian government to regain this land, but there would not be much of a political advantage in doing so. While regaining the Pechory region would satisfy ethnic Estonians by getting back a piece of land they felt was rightfully and legally theirs for decades, the region now is almost entirely Russian. Less than one percent of the population actually speaks Estonian. Were Estonia to annex the Pechory region, it could lead to greater tensions between Estonians and Russians (Stoicescu).

The Russian invasion of Crimea in 2014 made the Baltic States concerned that Russia could invade their countries next. The Russian government claimed to have occupied Crimea, 
a part of Ukraine at the time, to protect its ethnic Russian population, as 60 percent of the population of Crimea is ethnically Russian (Marshall 25). However, gaining control of Crimea aided Russia geopolitically, and the geopolitical gain is the suspected reason that Russia actually invaded the region. Crimea is a peninsula that held a former Russian port in Sevastopol. It was one of the few warm water ports Russia had in its possession, for many of its other ports are cold water ports that freeze. Additionally, the port was in the Black Sea, giving Russia ease of access to this sea and the Mediterranean Sea beyond. Access to these bodies of water is important to Russia so that it could defend itself from outsiders in the case of a war (Marshall 23-25).

Russia's concern about the sovereignty of the Russian people in Crimea is similar to the concern Russia expresses about the treatment of ethnic Russians in the Baltics. Theoretically, Russia could use the same argument of protecting ethnically Russian peoples to justify an invasion of the Baltic states. In Estonia, the invasion of Crimea alarmed the government because Estonia has a region that is very similar to Crimea: Narva. As discussed above, Narva's population is almost entirely Russian and is geographically very close to Russia itself. Russophones living in the region have complained that the Estonian government does not take them into consideration when creating policy and that the government has restricted their rights (Upadhyay 161). Considering Narva's similarities to Crimea, Estonia has gone out of its way to increase military activity in the region, most notably through an independence parade put on by the Estonian military and NATO troops, which triggered Russian demonstrations of military force through ballistic missile deployments close to the Estonian-Russian border (Upadhyay 162).

Russia continues to try to exercise its power over the region through whatever means it can. It has used military tactics to intimidate Estonia and has also tried to exercise its soft power by extending its influence through the media in the Baltic states. Interestingly, a significant number of Lithuanians continue to rely on Russia for some of the nations' news, though the country is no longer part of the Soviet Union and lacks a large ethnically Russian population (Maliukevicius 150). Russian news media is also prevalent among Russophones in Estonia and Latvia, countries that have significant Russophone populations (Grigas 10). This could very well be an effort Russia is taking in order to exercise some form of control over the Baltic states through soft power.

\section{| Conclusion}

Baltic-Russian relations are strained today because of Russia's concern for its geopolitical security. Ethnic politics and territorial disputes exacerbated pre-existing conflict between the nations and have led to years of Russian intimidation, which is unlikely to cease in the coming years. Although the Baltics have had strained relations with Russia for decades, it seems as though the Baltic governments are taking steps to reach out and build a stronger connection with their eastern neighbor. For example, Estonian President Kersti Kaljulaid met with Vladimir Putin in 2019 to reopen the Estonian embassy in Moscow ("Gallery"). While on the surface this may seem like a simple act meant to bring the two countries together, it is quite possible given the identity divisions in Estonia and the situation in Crimea that the Estonian government wanted to create better ties to Russia to protect themselves from 
future Russian aggression. Estonian policymakers could be taking this diplomatic step as a preventative measure rather than a genuine effort to become allies with Russia. Since Russian influence and intimidation towards the Baltic states will likely only increase, future BalticRussian relations will reflect the increasing importance of reconciliation between the powers. The relationship between the Baltic states and Russia will most likely continue to be a cold one, but Russian influence and intimidation may ultimately bring the countries closer than the Baltic states would like. 


\section{References}

Aalto, Pami. "Beyond Restoration: The Construction of Post-Soviet Geopolitics in Estonia." Cooperation and Conflict, vol. 35, no. 1, 2000, pp. 65-88. JSTOR, www.jstor.org/ stable/45083164.

Aasland, Aadne. "Citizenship Status and Social Exclusion in Estonia and Latvia." Journal of Baltic Studies, vol. 33, no. 1, 2002, pp. 57-77. JSTOR, www.jstor.org/stable/43212458.

"Commonwealth of Independent States." Encyclopaedia Britannica. www. britannica.com/ topic/Commonwealth-of-Independent-States.

Ehala, Martin. "The Bronze Soldier: Identity Threat and Maintenance in Estonia." Journal of Baltic Studies, vol. 40, no. 1, 2009, pp. 139-158. JSTOR, www.jstor.org/stable/43212867.

"Gallery: Kaljulaid attends reopening of Estonian Embassy in Moscow." ERR, news.err. ee/931264/gallery-kaljulaid-attends-reopening-of-estonian-embassy-in-moscow.

Grigas, Agnia. "Legacies, Coercion and Soft Power: Russian Influence in the Baltic States." Chatham House, Aug. 2012.www.chathamhouse.org/sites/default/files/public/Research/ Russia\%20and\%20Eurasia/0812bp_grigas.pdf. Accessed 20 Apr. 2020.

Heri, Corina. “The Fourth Section's Curious Take on Article 10 in Petropavlovskis v. Latvia: Two Comments." Strasbourg Observers, strasbourgobservers.com/2015/01/28/the-fourth-sectionscurious-take-on-article-10-in-petropavlovskis-vlatvia-two-comments/\#more-2751.

Herzog, Stephen. "Ten Years after the Estonian Cyberattacks: Defense and Adaptation in the Age of Digital Insecurity." Georgetown Journal of International Affairs, vol. 18, no. 3, 2017, pp. 67-78. JSTOR, www.jstor.org/stable/26395925.

"The History." The Singing Revolution. singingrevolution.com/about-the-history. Accessed 22 Apr. 2020.
"History of Latvia: A brief synopsis." Embassy of the Republic of Latvia to the United States of America, www.mfa.gov.Iv/en/usa/culture/history-of-latvia-a-brief-synopsis. Accessed 1 July 2020.

Hoellerbauer, Simon. "Baltic Energy Sources: Diversifying Away from Russia." Foreign Policy Research Institute, www.fpri.org/article/2017/06/ baltic-energy-sources-diversifying-away-russial. Accessed 1 July 2020.

Kundu, Nivedita Das. "Russia's Baltic Security Dilemma." India Quarterly, vol. 59, no. 1/2, 2003, pp. 59-72. JSTOR, www.jstor.org/ stable/45073510.

Lannin, Patrick and Jorgen Johansson. "Latvian anti-government protest turns into riot." Reuters, 13 Jan. 2009. www.reuters.com/article/us-latvia-protest/latvian-anti-government-protest-turns-into-riot-idUSTRE50C7IF20090113.

Maliukevicius, Nerijus. "Russia's Information Policy in Lithuania: The Spread of Soft Power or Information Geopolitics?" Baltic Security and Defence Review, vol. 9, 2007, pp. 150-170, appc.Iv/wp-content/uploads/2009/11/NerijusMaliukevicius.pdf. Accessed 24 Apr. 2020.

Mälksoo, Lauri. "Kononov v. Latvia." The American Journal of International Law, vol. 105, no. 1, 2011, pp. 101-108. JSTOR, www.jstor.org/ stable/10.5305/amerjintelaw.105.1.0101.

Marshall, Tim. Prisoners of Geography: Ten Maps That Tell You Everything You Need To Know About Global Politics. Scribner, 2015.

McLaughlin, Daniel. "Estonia closes Moscow embassy as president berates Russia." The Irish Times. www.irishtimes.com/news/estonia-closes-moscow-embassy-as-president-berates-russia-1.1204026.

"Obtaining Estonian Citizenship." Work Estonia, www.workinestonia.com/living-in-estonia/ita/obtaining-citizenship/. Accessed 23 Apr. 2020. 
"Restoration of Independence in the Baltics." Baltic Defence College, www.baltdefcol. org/?id=1243.

"Soviet power in Eastern Europe." BBC,www. bbc.co.uk/bitesize/guides/z9wxj6f/revision/1. Accessed 18 April 2020.

Stoicescu, Kalev. "The Tartu Peace Treaty and Estonia's Eastern Border." International Centre for Defence and Security, icds.ee/the-tartupeace-treaty-and-estonias-eastern-border/. Accessed 20 Apr. 2020.

Thompson, Wayne C. "Citizenship and Borders: Legacies of Soviet Empire in Estonia." Journal of Baltic Studies, vol. 29, no. 2, 1998, pp. 109-134. JSTOR, www.jstor.org/ stable/43212255.

Upadhyay, Archana. "Borderland Geopolitics In Estonia: The Case of 'Narva' - The Russian Majority Enclave." World Affairs: The Journal of International Issues, vol. 21, no. 3, 2017, pp. 160-169. JSTOR, www.jstor.org/ stable/48531360.

Veemaa, Jaanus. "Contextualizing 'Baltic Unity' in Estonian Post-Soviet Territorial Policies." Journal of Baltic Studies, vol. 41, no. 1, 2010, pp. 73-90. JSTOR, www.jstor.org/ stable/43212934.

The World Factbook. Central Intelligence Agency. www.cia.gov/library/publications/the-world-factbook/geos/lg.html. Accessed 17 Apr. 2020. 